\title{
Use of strontium in the activation of bovine oocytes reconstructed by somatic cell nuclear transfer
}

\author{
Walt Yamazaki ${ }^{1}$, Christina Ramires Ferreira ${ }^{1}$, Simone Cristina Méo ${ }^{1}$, Cláudia Lima Verde Leal ${ }^{2}$, \\ Flávio Vieira Meirelles ${ }^{2}$ and Joaquim Mansano Garcia ${ }^{1}$ \\ Departamento de Medicina Veterinária Preventiva e Reprodução Animal, FCAV - UNESP, SP, Brazil and Departamento \\ de Ciências Básicas, FZEA - USP, SP, Brazil
}

Date submitted: 14.02.05. Date accepted: 29.04.05

\section{Summary}

\begin{abstract}
As an important step in the nuclear transfer (NT) procedure, we evaluated the effect of three different treatments for oocyte activation on the in vitro and in vivo developmental capacity of bovine reconstructed embryos: (1) strontium, which has been successfully used in mice but not yet tested in cattle; (2) ionomycin and 6-dimethylaminopurine (6-DMAP), a standard treatment used in cattle; (3) ionomycin and strontium, in place of 6-DMAP. As regards NT blastocyst development, no difference was observed when strontium $(20.1 \%)$ or ionomycin/6-DMAP $(14.4 \%)$ were used. However, when 6-DMAP was substituted by strontium (3), the blastocyst rate $(34.8 \%)$ was superior to that in the other activation groups $(p<0.05)$. Results of in vivo development showed the possibility of pregnancies when NT embryos activated in strontium were transferred to recipient cows (16.6\%). A live female calf was obtained when ionomycin/strontium were used, but it died 30 days after birth. Our findings show that strontium can be used as an activation agent in bovine cloning procedures and that activation with a combination of strontium and ionomycin increased the in vitro developmental capacity of reconstructed embryos. This is the first report of a calf produced by adult somatic cell NT in Latin America.
\end{abstract}

Keywords: Bovine, Cloning, Oocyte activation, Somatic cell, Strontium

\section{Introduction}

The production of viable offspring using differentiated somatic cells collected from an adult animal in the process of cloning by nuclear transfer (NT) has increased significantly the interest of many researchers in this area, due to the great potential of its applications on the animal production industry, as well as for biopharmaceutical and medical purposes. Since the first successful report of adult cloning in sheep (Wilmut et al., 1997), efforts have been made to produce viable offspring using somatic cells in other species, such as cattle (Kato et al., 1998), mice (Wakayama et al., 1998),

All correspondence to: W. Yamazaki: DMVPRA - FCAV UNESP, Via de Acesso Prof. Paulo Donato Castelane, s/n, 14884-900, Jaboticabal-SP, Brazil. Tel: +55 1632092633. Fax: + 55163202 4275. e-mail: wyamazaki@yahoo.com

${ }^{1}$ Departamento de Medicina Veterinária Preventiva e Reprodução Animal, FCAV - UNESP, Via de Acesso Prof. Paulo Donato Castelane, s/n, 14884-900, Jaboticabal, SP, Brazil.

${ }^{2}$ Departamento de Ciências Básicas, FZEA - USP, Av. Duque de Caxias Norte, 225, CEP 13635-900, Pirassununga, SP, Brazil. goat (Baguisi et al., 1999) and swine (Polejaeva et al., 2000). However, several problems have been observed in somatic cell NT (Wilmut et al., 2002), presenting a great variability in the results of in vitro embryo development and development to term (Westhusin et al., 2001; Chavatte-Palmer et al., 2004). Many different factors may be influencing the results of NT, such as the techniques used for embryo reconstruction, cell type and state of differentiation of the nucleus donor, cell cycle synchronization, embryo culture systems and activation of the reconstructed oocyte (Westhusin et al., 2001; Heyman et al., 2002b).

Recognized as one of the important steps during the NT procedure, artificial activation of the reconstructed oocyte is necessary to allow chromatin decondensation and embryo development. Different agents have been used to induce oocyte activation, and the majority of the protocols used in NT were adopted from previous studies describing oocyte parthenogenetic activation (Fissore et al., 1999). In this way, the process of artificial activation must be optimized in NT for each species used, aiming to increase the development potential of reconstructed oocytes to reach the blastocyst stage and produce viable offspring. 
Incubation in ionomycin, which acts by promoting $\mathrm{Ca}^{2+}$ influx, combined with 6-dimethylaminopurine (6-DMAP), a protein phosphorylation inhibitor, is one of the most widely used activation protocols for reconstructed bovine oocytes after NT (Galli et al., 1999; Wells et al., 1999). However, being a broadspectrum phosphorylation inhibitor (Verlhac et al., 1993), 6-DMAP may act and interfere in many different events of protein phosphorylation that are important to embryo development and nucleus reprogramming, which could decrease the development potential of these embryos.

In mice, strontium has been successfully used in the process of activation of reconstructed oocytes (Wakayama et al., 1998; Amano et al., 2001). It has been reported that strontium is able to induce calcium oscillations in mouse oocytes in a similar pattern to that caused by spermatozoa during fertilization (BosMikich et al., 1997), and repeated calcium rises seem to be beneficial for later embryo development (Vitullo \& Ozil, 1992). Previous experiments from our laboratory have shown that strontium can also be used for the activation of bovine oocytes (Leal et al., 2003; Méo et al., 2004a,b). However, there are no reports on its application in bovine cloning.

In this study, we investigated the use of strontium as an activating agent in reconstructed bovine oocytes. The ability of embryos activated in strontium to undergo blastocyst development, establish pregnancy and generate live newborn was evaluated. We also assessed the effect of the substitution of 6-DMAP by strontium, when used as the second activation agent in combination with ionomycin.

\section{Materials and methods}

Except when indicated, all chemicals were obtained from Sigma Chemical (St Louis, MO).

\section{Preparation of donor karyoplasts}

The adult cell line used as nucleus donor was derived from a skin biopsy obtained from a 16-year-old Nelore cow (Bos indicus). The tissue biopsy was cut into small pieces $(3 \mathrm{~mm})$ and the explants were cultured in $25 \mathrm{~mm}^{2}$ flasks containing Dulbecco's modified Eagle's medium (DMEM; Gibco BRL, Grand Island, NY) supplemented with $40 \%$ fetal calf serum (FCS) and $75 \mathrm{mg} / \mathrm{ml}$ kanamycin (Gibco BRL, Grand Island, NY, USA) at $37^{\circ} \mathrm{C}$ under an atmosphere of $5 \% \mathrm{CO}_{2}$ in air and maximum humidity. This medium was used only during the first 3 days of culture during the process of primary cell line establishment. After that, cell culture was maintained using DMEM plus $10 \%$ FCS and kanamycin. When primary cell line confluence was achieved at 10 days, cells were treated with $0.25 \%$ trypsin and $0.1 \%$ EDTA. All passages were cultured until confluence (usually 7 days). Small aliquots of cells in the early passages were frozen in DMEM supplemented with $10 \%$ glycerol and stored in liquid nitrogen. Cell lines cultured for three to nine passages were used in NT experiments. Serum starvation (DMEM + 0.5\% FCS) was performed for 5-12 days before embryo reconstruction (Wilmut et al., 1997; Kato et al., 1998). Immunohistochemical staining was performed using monoclonal antibodies for detection of vimentin (Monoclonal Anti-Vimentin Clone V9) and cytokeratin (Monoclonal Anti-Pan Cytokeratin Clone C-11 FITC Conjugate) intermediate filaments for characterization of donor cells. The absence of epithelial cells (cytokeratin-negative) and the positive staining for vimentin in all cell lines analysed (passages 2, 4 and 6), suggest that donor cells were in fact fibroblasts.

\section{In vitro maturation}

Cumulus-oocyte complexes (COCs) were obtained from ovaries of slaughtered cows (Bos taurus). Follicles 3-8 $\mathrm{mm}$ in diameter were aspirated using an 18-gauge needle attached to a $20 \mathrm{ml}$ syringe. COCs with compact cumulus cells (more than three layers of cumulus) and homogeneous cytoplasm were selected for in vitro maturation (IVM). Selected COCs were washed twice in HEPES-buffered Tissue Culture Medium 199 (TCM199, Gibco BRL) plus 10\% FCS and further in bicarbonate-buffered TCM-199 supplemented with 10\% FCS, $100 \mathrm{IU} / \mathrm{ml}$ hCG (Profasi; Serono, Sāo Paulo, Brazil), $1 \mathrm{mg} / \mathrm{ml}$ FSH (Folltropin; Bioniche Animal Health Belleville, ON, Canada), $1 \mathrm{mg} / \mathrm{ml}$ estradiol, $16 \mathrm{mg} / \mathrm{ml}$ pyruvate and $75 \mathrm{mg} / \mathrm{ml}$ kanamycin. Ten to twenty COCs were cultured for IVM in $100 \mathrm{ml}$ drops in $60 \mathrm{~mm}$ plastic dishes under mineral oil at $38.5^{\circ} \mathrm{C}$ under $5 \% \mathrm{CO}_{2}$ in air and maximum humidity.

\section{In vitro fertilization}

As control for in vitro development, a group of oocytes was submitted to in vitro fertilization (IVF). At $24 \mathrm{~h}$ post-maturation, expanded COCs were transferred to $100 \mathrm{ml}$ drops of TALP-IVF medium supplemented with $6 \mathrm{mg} / \mathrm{ml}$ bovine serum albumin (BSA), $10 \mathrm{mg} / \mathrm{ml}$ heparin, $2 \mathrm{~mm}$ penicillamine, $1 \mathrm{~mm}$ hypotaurine and $0.25 \mathrm{~mm}$ epinephrine for insemination. Frozen semen was used and motile spermatozoa were separated by density gradient separation in $45 \%$ and $90 \%$ Percoll. The final sperm concentration used was $2.5 \times 10^{6}$ live spermatozoa $/ \mathrm{ml}$. Oocytes and sperm cells were co-incubated for $18 \mathrm{~h}$ at $38.5^{\circ} \mathrm{C}$ under $5 \% \mathrm{CO}_{2}$ in air and maximum humidity. At the end of co-culture, presumptive zygotes were washed in TALP-IVF medium to remove cumulus cells and 
attached spermatozoa, and transferred to embryo culture medium.

\section{Nuclear transfer}

In this experiment, we used fibroblasts from a Bos indicus Nelore cow as nucleus donors, and oocytes from Bos taurus animals as cytoplasm donors. This combination of nucleus and cytoplasm donors is being used as part of an investigation of the patterns of mitochondrial DNA (mtDNA) segregation in somatic cell NT. As the main purpose of this experiment was to investigate the use of strontium in the activation of reconstructed oocytes, results related to mtDNA segregation will be presented elsewhere.

For the NT procedure, at $21 \mathrm{~h}$ post-maturation, expanded COCs were placed in $0.2 \%(\mathrm{v} / \mathrm{v})$ hyaluronidase for $5 \mathrm{~min}$ and gentle pipetting was performed to remove the cumulus cells. Oocytes with a first polar body were selected and then incubated in HEPES-buffered synthetic oviduct fluid (HSOF) (Wells et al., 1999) with $10 \mathrm{mg} / \mathrm{ml}$ Hoechst 33342 stain and $7.5 \mathrm{mg} / \mathrm{ml}$ cytochalasin B. Oocytes were enucleated with a $25 \mathrm{~mm}$ (external diameter) glass pipette, by removing the first polar body and the surrounding cytoplasm at between 22 and $24 \mathrm{~h}$ postmaturation. Enucleation was confirmed by visualizing the aspirated karyoplast inside the pipette under ultraviolet light. After enucleation, cytoplasts were washed twice in HSOF $+10 \%$ FCS and held in this medium until reconstruction. Individual fibroblast cells were transferred into the perivitelline space of each recipient oocyte in HSOF containing $10 \%$ FCS and $7.5 \mathrm{mg} / \mathrm{ml}$ cytochalasin B. The oocyte-cell complexes were fused in $0.28 \mathrm{M}$ mannitol solution containing $0.05 \mathrm{~mm}$ calcium and $0.1 \mathrm{~mm}$ magnesium. Cell fusion was induced with two direct pulses of $2.25 \mathrm{kV} / \mathrm{cm}$ for $20 \mathrm{~ms}$ each, using a BTX Electrocell Manipulator 2001 (BTX, San Diego, CA). Fusion rates were determined 30-60 min after electrofusion, and successfully reconstructed oocytes were incubated in $\mathrm{HSOF}+10 \% \mathrm{FCS}$ at $38.5^{\circ} \mathrm{C}$ under a humidified atmosphere of $5 \% \mathrm{CO}_{2}$ in air until activation.

\section{Activation of reconstructed oocytes}

Reconstructed oocytes were chemically activated at $30 \mathrm{~h}$ post-maturation, using three different protocols: strontium $\left(\mathrm{SrCl}_{2} \cdot 6 \mathrm{H}_{2} \mathrm{O}\right.$, Riedel-de-Haën, VETEC, Rio de Janeiro, Brazil); ionomycin combined with 6-dimethylaminopurine (6-DMAP), or ionomycin combined with strontium. Activation in strontium was achieved by incubation in $20 \mathrm{~mm} \mathrm{SrCl}_{2}$ supplemented with $10 \mathrm{mg} / \mathrm{ml}$ cytochalasin B in TALP-IVF medium without $\mathrm{Ca}^{2+}$ or $\mathrm{Mg}^{2+}$ for $6 \mathrm{~h}$. This concentration of strontium $(20 \mathrm{~mm})$ was adopted on the basis of previous results obtained in our laboratory related to bovine parthenogenetic activation using different concentrations of $\mathrm{SrCl}_{2}$ (Méo et al., 2005). When ionomycin + 6-DMAP was used, reconstructed oocytes were incubated in HSOF $+10 \%$ FCS containing $5 \mathrm{~mm}$ ionomycin for $5 \mathrm{~min}$, washed several times in HSOF $+10 \%$ FCS before incubation in modified Synthetic Oviduct Fluid (SOF) supplemented with $2 \mathrm{~mm}$ 6-DMAP for $4 \mathrm{~h}$. In the third group, reconstructed oocytes were activated using ionomycin $(5 \mathrm{~mm})$ in $\mathrm{HSOF}+10 \%$ FCS for $5 \mathrm{~min}$ followed by incubation in SOF supplemented with $20 \mathrm{~mm} \mathrm{SrCl}_{2}$ and $10 \mathrm{mg} / \mathrm{ml}$ cytochalasin B for $6 \mathrm{~h}$.

\section{Activation of control oocytes (parthenogenetic controls)}

Cumulus cells from oocytes matured for $24 \mathrm{~h}$ were removed in $0.2 \%$ hyaluronidase $(5 \mathrm{~min})$ and those with a first polar body and homogeneous cytoplasm were selected for activation. Selected oocytes were held in maturation medium until activation. At $30 \mathrm{~h}$ post-maturation, oocytes were activated in strontium supplemented with cytochalasin B, ionomycin + 6-DMAP, or ionomycin + strontium supplemented with cytochalasin B, as described previously for activation of reconstructed oocytes.

\section{In vitro development}

Embryo culture was performed in $100 \mathrm{ml}$ microdrops of modified SOF (Vajta et al., 1999) containing $5 \mathrm{mg} / \mathrm{ml}$ fatty-acid-free BSA and 5\% FCS, overlaid with mineral oil. Groups of 10-20 embryos were cultured together in each microdrop at $38.5^{\circ} \mathrm{C}$ under a humidified atmosphere of $5 \% \mathrm{CO}_{2}$ in air. Embryos from NT groups, IVF and parthenogenetic control groups were evaluated for cleavage (day 2) and blastocyst development rates (day 7). A proportion of the embryos that reached the blastocyst stage in all groups were fixed and stained with Hoechst $33342(10 \mathrm{mg} / \mathrm{ml})$, and the total cell number was determined under an epifluorescence microscope (Olympus IX-70).

\section{In vivo development of NT embryos}

To assess in vivo development of reconstructed embryos activated in strontium, one or two good-quality day 7 blastocysts from NT groups activated in strontium or in ionomycin + strontium were transferred nonsurgically into the uterus of previously synchronized recipient cows. Recipients were examined for pregnancy by ultrasonography or palpated per rectum on days 50, 60 and 90 of gestation and allowed to develop to term. 
Table 1 Developmental rates and total cell number of bovine IVF, parthenogenetic (ATV) and nuclear transfer (NT) embryos using different activation treatments

\begin{tabular}{|c|c|c|c|c|}
\hline Group & Cultured $^{*} N$ & Cleaved $N(\%)$ & Blastocysts $N(\%)$ & Total cell number \\
\hline IVF & 430 & $311(72.3)^{a}$ & $111(25.8)^{a b}$ & $91.5 \pm 17.5(n=10)^{a}$ \\
\hline ATV-Sr ${ }^{2+}$ & 191 & $94(49.2)^{a}$ & $24(12.6)^{c}$ & $73.1 \pm 12.6(n=10)^{a b}$ \\
\hline ATV-Ion/6-DMAP & 199 & $160(80.4)^{a}$ & $68(34.2)^{d}$ & $75.4 \pm 14.5(n=10)^{a b}$ \\
\hline ATV-Ion/Sr ${ }^{2+}$ & 218 & $192(88.1)^{a}$ & $90(41.3)^{d}$ & $82.7 \pm 13.4(n=10)^{a b}$ \\
\hline NT-Sr ${ }^{2+}$ & 134 & $91(67.9)^{a}$ & $27(20.1)^{b c}$ & $62.6 \pm 11.1(n=8)^{b}$ \\
\hline NT-Ion/6-DMAP & 125 & $88(70.4)^{a}$ & $18(14.4)^{b c}$ & $62.8 \pm 7.1(n=5)^{b}$ \\
\hline NT-Ion $/ \mathrm{Sr}^{2+}$ & 129 & $104(80.6)^{a}$ & $45(34.9)^{d}$ & $67.8 \pm 6.8(n=8)^{b}$ \\
\hline
\end{tabular}

$\mathrm{Sr}^{2+}$, strontium; Ion/6-DMAP, ionomycin + 6-DMAP; Ion $/ \mathrm{Sr}^{2+}$, ionomycin + strontium.

*Total oocytes used for IVF and parthenogenetic activation in control groups, and total reconstructed oocytes fused and cultured.

${ }^{a-d}$ Different letters within columns indicate statistical difference at a level of $5 \%$.

\section{Microsatellite analyses}

Four polymorphic microsatellite loci (ETH 225, ILSTS 005, INRA 063 and HEL 9) previously tested in zebu cattle were analysed individually to confirm the resulting calf identity. DNA samples of nuclear donor female were extracted from blood and fibroblast cells as described earlier (Sambrook \& Russel, 2001). Identity with the resulting female calf was tested by applying DNA extracted from jugular blood and from umbilical cord vein and recipient DNA extracted from jugular blood. All other female Nelore cells housed in the laboratory had the DNA extracted and were analysed as counter-proofs. A positive result was achieved by an exact mach of the four loci between the nuclear donor cow and derived calf, and mismatch of at least one of the matches in other animals. Maternity of the surrogate mother was also excluded by coat colour and morphological characteristics.

\section{Statistical analysis}

Cleavage and blastocyst development rates of NT and control groups (IVF and parthenogenetic activation) were compared by the chi-square test. Total cell number in blastocysts was compared by the Tukey test using the GLM procedure of SAS $(p<0.05$ was considered significant).

\section{Results}

\section{In vitro development}

Results regarding in vitro development of IVF, parthenogenetic and NT embryos are presented in Table 1. Cleavage rates were similar in all groups, ranging from $67.9 \%$ to $88.1 \%(p>0.05)$, except for the parthenogenetic group activated with strontium $(42.9 \%, p<0.05)$. Results of the control groups showed a lower blastocyst rate $(p<0.05)$ when activation was performed using strontium (ATV-Sr $\left.{ }^{2+}, 12.5 \%\right)$ in comparison with parthenotes activated in ionomycin combined with 6-DMAP (ATV-Ion /6-DMAP, 34.2\%) or with strontium (ATV-Ion/Sr ${ }^{2+}, 41.3 \%$ ). No differences were observed in blastocyst development between the parthenogenetic groups activated in ionomycin combined with 6-DMAP or strontium, but these results were superior to the IVF control group $(25.8 \%, p<$ $0.05)$. The developmental rate to the blastocyst stage in NT groups was similar when strontium or ionomycin combined with 6-DMAP were used as activating agents ( $20.1 \%$ and $14.4 \%$, respectively). However, ionomycin combined with strontium treatment resulted in a superior blastocyst rate $(34.9 \%)$ compared with the other NT groups $(p<0.05)$.

As regards total cell number of blastocysts, NT groups $(62.6 \pm 11.1,62.8 \pm 7.1$ and $67.8 \pm 6.8$ cells for NT-Sr ${ }^{2+}$, NT-Ion/6-DMAP and NT-Ion/ $/ \mathrm{Sr}^{2+}$, respectively, $p>0.05$ ) were inferior to the IVF control group $(91.5 \pm 17.5$ cells, $p<0.05)$. No differences were observed $(p>0.05)$ in the total cell number among all the parthenogenetic control groups $(73.1 \pm 12.6,75.4 \pm 14.5$ and $82.7 \pm 13.4$ cells for ATV-Sr ${ }^{2+}$, ATV-Ion/6-DMAP and ATV-Ion $/ \mathrm{Sr}^{2+}$, respectively) when compared with NT groups.

These results for in vitro development clearly demonstrate a better embryo development for NT embryos in the combined activation treatment using ionomycin and strontium, although the increase in blastocyst rates does not guarantee improved embryo quality, considering total cell number.

\section{In vivo development}

From a total of 19 blastocysts produced by NT using strontium or ionomycin combined with strontium to induce oocyte activation, 3 recipients out of 11 were pregnant on day 50 (Table 2). On day 60 , the 3 recipients 


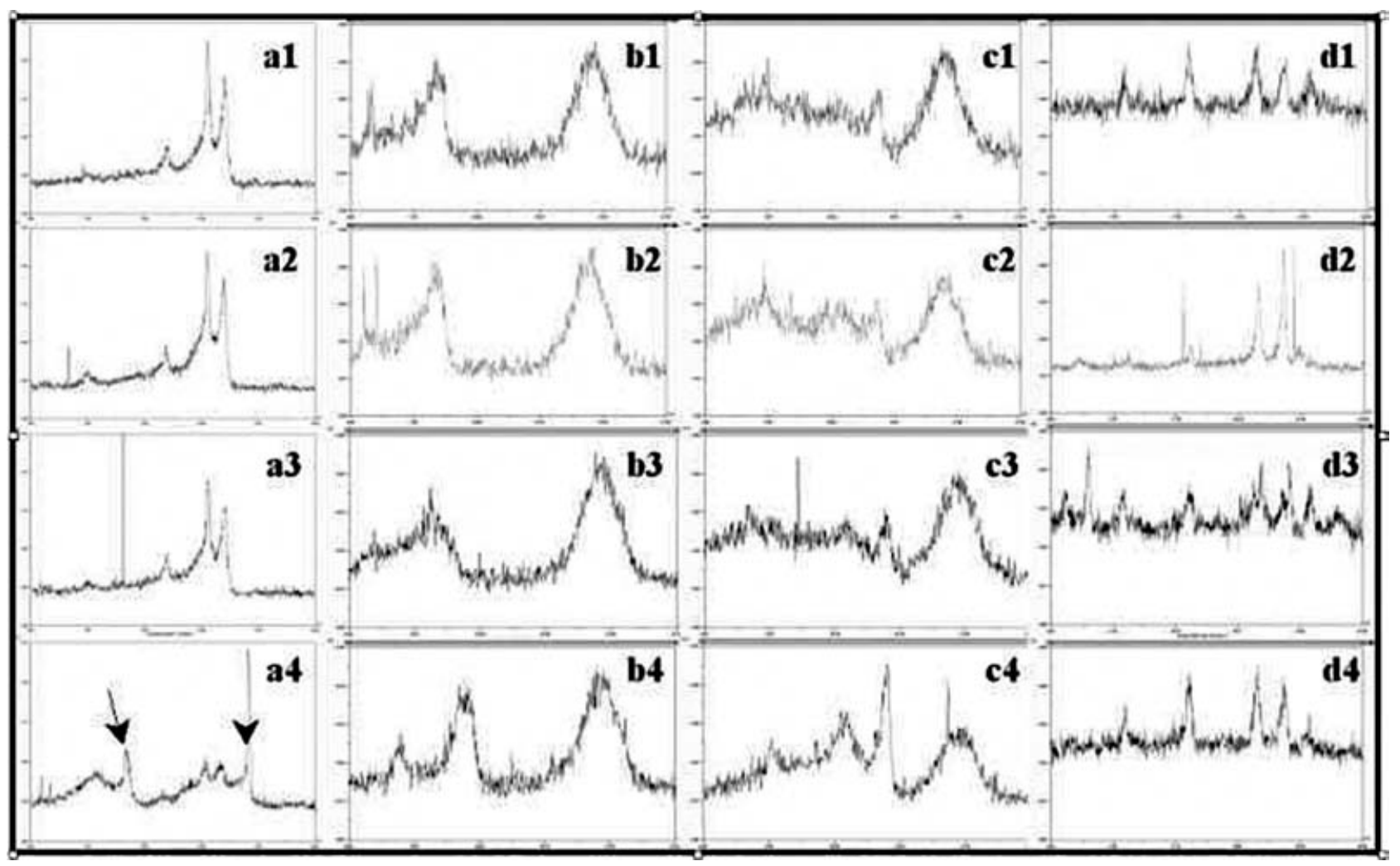

Figure 1 Electrophoresis of microsatellite markers of cloned calf (1), nuclei donor cow (2: extracted from blood; 3: extracted from fibroblast cells in culture) and surrogate cow (4). Column (a) shows the band pattern of microsatellite ETH 225, showing divergence between all samples.

Table 2 Pregnancy and full-term development of bovine nuclear transfer (NT) embryos using strontium $\left(\mathrm{Sr}^{2+}\right)$ or ionomycin combined with strontium $\left(\mathrm{Ion} / \mathrm{Sr}^{2+}\right)$ as activating agents

\begin{tabular}{|c|c|c|c|c|c|}
\hline \multirow[b]{2}{*}{ Group } & \multirow{2}{*}{$\begin{array}{c}\text { Embryos } \\
\text { transferred } N\end{array}$} & \multirow[b]{2}{*}{ Recipients $N$} & \multicolumn{2}{|c|}{$\begin{array}{l}\text { Pregnant recipients } \\
\text { on day }{ }^{a} N(\%)\end{array}$} & \multirow{2}{*}{$\begin{array}{c}\text { Calves born } \\
\quad N(\%)\end{array}$} \\
\hline & & & 50 & $60-90$ & \\
\hline NT- $\left(\mathrm{Sr}^{2+}\right)$ & 12 & 6 & $1(16.7)$ & 0 & 0 \\
\hline NT-(Ion/Sr ${ }^{2+}$ ) & 7 & 5 & $2(40.0)$ & $1(20.0)$ & $1(14.3)$ \\
\hline Total & 19 & 11 & $3(27.3)$ & $1(9.1)$ & $1(5.3)$ \\
\hline
\end{tabular}

$\mathrm{Sr}^{2+}$, strontium; Ion, ionomycin.

${ }^{a}$ Regarding the number of recipients.

${ }^{b}$ Regarding the number of transferred embryos.

remained pregnant, as confirmed by ultrasonography. Activation by strontium alone resulted in one pregnancy with one fetus, while two pregnancies and two live fetuses were obtained in NT groups submitted to activation by ionomycin and strontium. One fetus from each group was lost between days 60 and 90. From the remaining recipient, pregnant of a fetus from the NT group activated in ionomycin and strontium, one live female Nelore calf (Bos indicus) was delivered by caesarean section at day 290 of gestation after induction of parturition with dexamethasone $30 \mathrm{mg}$ intramuscularly, 2 days before surgery. The newborn weighed $42 \mathrm{~kg}$; and was apparently normal. Unfortunately, the animal died of septicemia and peritonitis 1 month after birth.

\section{Microsatellite analyses}

The analysis of microsatellite loci revealed that the amplified fragments lengths of the female calf matched perfectly those of the nuclear donor cow at all four loci (Fig. 1). Only one locus (ILSTS 005) had the same size compared with the surrogate female and at least one locus had a different size compared with other female 
cells housed in the laboratory (Fig. 1). Taken together these results and the typical Nelore phenotype of the calf obtained allow the confirmation of the clonal origin of the calf.

\section{Discussion}

Metaphase II enucleated oocytes are usually used in NT production with somatic cells as nucleus donors. This cytoplasm source has, however, a need of an artificial activation to decrease maturation promoting factor (MPF) activity, allowing the transferred nucleus to progress to first interphase and initiate the events necessary for the beginning of embryo development (Fissore et al., 1999). Therefore, it is important that the biological events promoted by artificial activation of the reconstructed oocyte should be similar to those promoted by the process of a normal fertilization (Macháty \& Prather, 1998).

Studies using strontium have demonstrated the effectiveness of this activating agent to induce oocyte activation for both parthenogenetic development (BosMikich et al., 1997) and cloning (Wakayama et al., 1998; Amano et al., 2001) in mice. Although the resumption of meiotic division could be induced by a single calcium rise, higher embryonic development was observed when multiple rises in calcium levels were promoted by strontium to induce artificial activation of reconstructed oocytes in mice (Kishikawa et al., 1999). In cattle, previous results from our laboratory have shown that strontium is able to induce activation (Leal et al., 2003) and parthenogenetic development to the blastocyst stage (Méo et al., 2004, 2005) in cattle, suggesting that it may be possible to use this activating agent as an alternative method for activation procedures used for cloning by NT in this species.

In this experiment, in vitro development of reconstructed embryos activated in strontium was similar to that obtained using ionomycin and 6-DMAP, as well as being similar to the result of the IVF control group. This result supports the hypothesis that strontium can be used in bovine somatic cell NT to induce oocyte activation, with the same efficiency as a standard activation protocol (ionomycin and 6-DMAP) used in bovine cloning.

As 6-DMAP is a non-specific phosphorylation inhibitor (Verlhac et al., 1993), we also evaluated the effect of the substitution of 6-DMAP by strontium in the combined activation with ionomycin. This new protocol of activation (ionomycin and strontium) increased the blastocyst development of reconstructed embryos and was more effective than the other two treatments (strontium or ionomycin + 6-DMAP). Our hypothesis for this improvement in embryonic development potential is that a synergistic effect occurred when both agents were used together to induce the activation of the reconstructed oocytes, based on the fact that both ionomycin and strontium are calciumreleasing agents (Kline \& Kline, 1992), and strontium releases calcium in an oscillating fashion, which mimics more closely the activation events promoted by fertilization (Bos-Mikich et al., 1997). Activation of reconstructed oocytes with ionomycin would cause a first calcium release, with calcium influx from the extracellular medium and mobilization of internal stores (Kline \& Kline, 1992), while the subsequent incubation in strontium would result in periodic oscillations in calcium levels (Kline \& Kline, 1992; BosMikich et al., 1997), contributing to the occurrence of the cytoplasmic and nuclear changes necessary for initiating embryo development. This second stimulus could also activate reconstructed oocytes that would have not been activated by the first calcium release induced by ionomycin, increasing developmental rates. However, other studies are necessary to confirm this hypothesis, as it remains to be determined whether strontium induces calcium oscillations in bovine oocytes in the way that has been observed in mice.

The activation procedures resulted in good embryo development rates, independently of the activation protocol used. However, compared with IVF embryos, a lower NT embryo quality (assessed as total cell number in a blastocyst) was observed. A similar observation was reported previously (Daniels et al., 2001) and studies aiming to improve the activating protocol certainly remain to be pursued. The lower total cell number observed in our study in the NT blastocysts could interfere with the developmental capacity and establishment of pregnancy.

In order to evaluate the developmental capacity of reconstructed embryos activated in strontium to establish pregnancies and development to term, some embryos were transferred to recipient cows. Although some gestations were confirmed, results revealed high embryonic and fetal mortality during early pregnancy in both NT groups activated with strontium, combined or not with ionomycin. These high mortality rates during early pregnancy in cattle have been related to poor development of the placenta (Hill et al., 2000; Smith et al., 2000; De Sousa et al., 2001), as well as a lower capacity of the embryo to secrete interferon-tau (Stojkovic et al., 1999). These observed deficiencies have been attributed to incomplete nuclear reprogramming and abnormal expression of certain genes during embryo development (Daniels et al., 2000; Rideout III et al., 2001; Wrenzycki et al., 2001). Although higher in vitro development was observed when reconstructed oocytes were activated in ionomycin and strontium in comparison with the others NT groups, this was not reflected in the in vivo development and development 
to term. Only one calf was obtained in the group activated with ionomycin and strontium. The newborn, named 'Penta', was apparently healthy after birth, but clinical complications such as fever, leucocytosis and diarrhoea started to develop in the third week of life of the clone. The animal was treated and intensive therapy was instituted, but unfortunately the calf died of septicemia.

An increased number of births of cloned animals using somatic cells has been reported in several species (Wilmut et al., 1997; Kato et al., 1998; Wakayama et al., 1998; Baguisi et al., 1999; Polejaeva et al., 2000), but the process of cloning is still inefficient. Birth rates were, in general, lower than 7\% (Heyman et al., 2002), and many cloned offspring die just after birth or within few days or weeks of life (Hill et al., 1999; Heyman et al., 2002; Wilmut et al., 2002). The comprehension of the events involving the nuclear reprogramming process, as well as the investigation of the effects of different activation protocols, in vitro maturation, embryo and cell culture systems on the developmental potential of NT embryos, will be important to improve the efficiency of somatic cell cloning.

In conclusion, our results indicate that strontium can be used in the activation of NT bovine embryos reconstructed with adult somatic cells, as demonstrated in cloning in the mouse. It was also shown that the substitution of 6-DMAP by strontium, in the combined activation with ionomycin, increased the in vitro development potential of NT embryos, allowing the establishment of pregnancies and development to term. To our knowledge, this is the first description of the production of offspring using strontium as an activating agent of NT bovine embryos. It is also the first report of a calf produced by adult somatic cell nuclear transfer in Latin America.

\section{Acknowledgements}

This work was supported by Fundaçāo de Amparo à Pesquisa do Estado de Sāo Paulo - FAPESP, Brazil.

\section{References}

Amano, T., Kato, Y. \& Tsunoda, Y. (2001). Full-term development of enucleated mouse oocytes fused with embryonic stem cells from different cell lines. Reproduction 121, 729-33.

Baguisi, A., Behdoodi, E., Melican, D.T., Pollock, J.S., Destrempes, M.M., Cammuso, C., Williams, J.L., Nims, S.D., Porter, C.A., Midura, P., Palacios, M.J., Ayres, S.L., Denniston, R.S., Hayes, M.L., Ziomek, C.A., Meade, H.M., Godke, R.A., Gavin, W.G., Overström, E.W. \& Echelard, Y. (1999). Production of goats by somatic cell nuclear transfer. Nat. Biotechnol. 17, 456-61.
Bos-Mikich, A., Whittingham, D.G. \& Jones, K.T. (1997). Meiotic and mitotic $\mathrm{Ca}^{2+}$ oscillations affect cell composition in resulting blastocysts. Dev. Biol. 182, 172-9.

Chavatte-Palmer, P., Remy, D., Cordonnier, N., Richard, C., Issenman, H., Laigre, P., Heyman, Y. \& Mialot, J.-P. (2004). Health status of cloned cattle at different ages. Cloning Stem Cells 6, 94-100.

Daniels, R., Hall, V.J., French, A.J., Korfiatis, N.A. \& Trounson, A.O. (2001). Comparison of gene transcription in cloned bovine embryos produced by different nuclear transfer techniques. Mol. Reprod. Dev. 60, 281-8.

Daniels, R., Hall, V. \& Trounson, A.O. (2000). Analysis of gene transcription in bovine nuclear transfer embryos reconstructed with granulosa cell nuclei. Biol. Reprod. 63, 1034-40.

De Sousa, P.A., King, T., Harkness, L., Young, L.E., Walker, S.K. \& Wilmut, I. (2001). Evaluation of gestational deficiencies in cloned sheep fetuses and placentae. Biol. Reprod. 65, 23-30.

Fissore, R.A., Long, C.R., Duncan, R.P. \& Robl, J.M. (1999). Initiation and organization of events during the first cell cycle in mammals: applications in cloning. Cloning 1, 89100.

Galli, C., Duchi, R., Moor, R.M. \& Lazzari, G. (1999). Mammalian leukocytes contain all the genetic information necessary for the development of a new individual. Cloning 1, 161-70.

Heyman, Y., Chavatte-Palmer, P., Le Bourhuis, D., Camous, S., Vignon, X. \& Renard, J.P. (2002a). Frequency and occurrence of late-gestation losses from cattle cloned embryos. Biol. Reprod. 66, 6-13.

Heyman, Y., Zhou, Q., Le Bourhuis, D., Chavatte-Palmer, P., Renard, J.P. \& Vignon, X. (2002b). Novel approaches and hurdles to somatic cloning in cattle. Cloning Stem Cells 4, 47-55.

Hill, J.R., Roussel, A.J., Cibelli, J.B., Edwards, J.F., Hooper, N.L., Miller, M.W., Thompson, J.A., Looney, C.R., Westhusin, M.E., Robl, J.M. \& Stice, S.L. (1999). Clinical and pathologic features of cloned transgenic calves and fetuses (13 case studies). Theriogenology 51, 1451-65.

Hill, J.R., Burghardt, R.C., Jones, K., Long, C.R., Looney, C.R., Shin, T., Spencer, T.E., Thompson, J.A., Winger, Q.A. \& Westhusin, M.E. (2000). Evidence for placental abnormality as the major cause of mortality in first-trimester somatic cell cloned bovine fetuses. Biol. Reprod. 63, 1787-94.

Kato, Y., Tani, T., Sotomaru, Y., Kurokawa, K., Kato, J.Y., Doguchi, H., Yasue, H. \& Tsunoda, Y. (1998). Eight calves cloned from somatic cells of a single adult. Science 282, 2095-8.

Kishikawa, H., Wakayama, T. \& Yanagimachi, R. (1999). Comparison of oocyte-activating agents for mouse cloning. Cloning 1, 153-9.

Kline, D. \& Kline, J.T. (1992). Repetitive calcium transients and the role of calcium in exocytosis and cell cycle activation in the mouse egg. Dev. Biol. 149, 80-9.

Leal, C.L.V., Méo, S.C. \& Garcia, J.M. (2003). Activation of bovine oocytes by strontium combined or not with electric pulse. Arq. Bras. Med. Vet. Zoot. 55, 371-3.

Macháty, Z. \& Prather, R.S. (1998). Strategies for activating nuclear transfer oocytes. Reprod. Fertil. Dev. 10, 599613. 
Méo, S.C., Leal, C.L.V. \& Garcia, J.M. (2004). Activation and early parthenogenesis of bovine oocytes treated with ethanol and strontium. Anim. Reprod. Sci. 81, 3546.

Méo, S.C., Yamazaki, W., Leal, C.L.V., Oliveira, J.A. de \& Garcia, J.M. (2005). Use of strontium for bovine oocyte activation. Theriogenology 8, 2089-102.

Polejaeva, I.A., Chen, S.H., Vaught, T.D., Pagem, R.L., Mullins, J., Ball, S., Dai, Y., Boone, J., Walker, S., Ayares, D.L., Colman, A. \& Campbell, K.H.S. (2000). Cloned pigs produced by nuclear transfer from adult somatic cells. Nature 407, 505-9.

Rideout III, W.M., Eggan, K. \& Jaenisch, R. (2001). Nuclear cloning and epigenetic reprogramming of the genome. Science 293, 1093-8.

Sambrook, J. \& Russel, D.W. (2001). Molecular Cloning: A Laboratory Manual. New York: Cold Spring Harbor Laboratory Press.

Smith, L.C., Bordignon, V., Babkine, M., Fecteau, G. \& Keefer, C. (2000). Benefits and problems with cloning animals. Can. Vet. J. 41, 919-24.

Stojkovic, M., Büttner, M., Zakhartchenko, V., Riedl, J., Reichenbach, H.D., Wenigerkind, H., Brem, G. \& Wolf, E. (1999). Secretion of interferon-tau by bovine embryos in long term culture: comparison of in vivo derived, in vitro produced, nuclear transfer and demiembryos. Anim. Reprod. Sci. 55, 151-62.

Vajta, G., Rindom, N., Peura, T.T., Holm, P., Greve, T. \& Callesen, H. (1999). The effect of media, serum and temperature on in vitro survival of bovine blastocysts after open pulled straw (OPS) vitrification. Theriogenology 52 939-48.

Verlhac, M.H., Pennart, H., Maro, B., Cobb, M.H. \& Clarke, H.J. (1993). MAP kinase becomes stably activated at metaphase and is associated with microtubule-organizing centers during meiotic maturation of mouse oocytes. Dev. Biol. 158, 330-40.

Vitullo, A.D. \& Ozil, J.P. (1992). Repetitive calcium stimuli drive meiotic resumption and pronuclear development during mouse oocyte activation. Dev. Biol. 151, 128-36.

Wakayama, T., Perry, A.C.F., Zuccotti, M., Johnson, K.R. \& Yanagimachi, R. (1998). Full-term development of mice enucleated oocytes injected with cumulus cell nuclei. Nature 394, 369-74.

Wells, D.N., Misica, P.M. \& Tervit, H.R. (1999). Production of cloned calves following nuclear transfer with cultured adult mural granulose cells. Biol. Reprod. 60, 996-1005.

Westhusin, M.E., Long, C.R., Shin, T., Hill, J.R., Looney, C.R., Pryor, J.H. \& Piedrahita, J.A. (2001). Cloning to reproduce desired genotypes. Theriogenology 55, 35-49.

Wilmut, I., Schnieke, A.E., McWhir, J., Kind, A.J. \& Campbell, K.H.S. (1997). Viable offspring derived from fetal and adult mammalian cells. Nature 385, 810-13.

Wilmut, I., Beaujean, N., De Sousa, P.A., Dinnyes, A., King, T.J., Paterson, L.A., Wells, D.N. \& Young, L.E. (2002). Somatic cell nuclear transfer. Nature 419, 583-6.

Wrenzycki, C., Wells, D., Herrmann, D., Miller, A., Oliver, J., Tervit, R. \& Niemann, H. (2001). Nuclear transfer protocol affects messenger RNA expression patterns in cloned bovine blastocysts. Biol. Reprod. 65, 309-17. 